\title{
PERANCANGAN SISTEM PENGUKURAN KINERJA KOPERASI DENGAN METODE BALANCED SCORECARD BERBASIS BORLAND DELPHI
}

\author{
Chauliah Fatma Putri, Silviana \\ Universitas Widyagama Malang \\ e-mail: ullychauliah_uwg@yahoo.com, silviana.hakim@yahoo.co.id
}

\begin{abstract}
Abstrak
Balanced Scorecard adalah suatu alat manajemen kinerja yang dapat membantu organisasi untuk menerjemahkan visi dan strategi ke dalam aksi dengan memanfaatkan sekumpulan indikator finansial dan non-finansial. Terdapat empat aspek yang diukur dalam Balanced Scorecard (BSC) yaitu perspektif keuangan, perspektif pelanggan, perspektif proses bisnis internal, serta perspektif pertumbuhan dan pembelajaran. Penelitian ini bertujuan untuk mengetahui bagaimana kinerja dari Koperasi Karyawan PWGM dengan menggunakan konsep Balanced Scorecard. Hasil identifikasi berdasarkan sasaran strategis (strategic objective) dan kebutuhan manajemen, terbentuk 26 KPI (Key Performance Indicator), terdiri atas 7 KPI pada perspektif keuangan, 6 KPI pada perspektif pelanggan, 9 KPI pada perspektif proses bisnis internal, dan 4 KPI pada perspektif pembelajaran dan pertumbuhan. Secara keseluruhan, indeks pencapaian kinerja pada Kopkar PWGM adalah kategori kurang baik dengan skor kinerja sebesar 3,800.
\end{abstract}

Kata kunci: Pengukuran Kinerja, Balanced Scorecard, Koperasi

\begin{abstract}
Balanced Scorecard is a performance management tool that can help organizations to translate vision and strategy into action by utilizing a set of financial indicators and non-financial. There are four aspects that are measured in the Balanced Scorecard (BSC) is a financial perspective, customer perspective, internal business processes, and learning and growth perspectives. This study aims to determine how the performance of Cooperative Employees PWGM using the Balanced Scorecard concept. Identification results based on strategic objectives (strategic objective) and management needs, formed 26 KPI (Key Performance Indicator), consisting of 7 KPI on the financial perspective, the customer perspective 6 KPI, 9 KPI on internal business process perspective, and 4 KPI on a learning perspective and growth. Overall, the achievement of the performance index on Kopkar PWGM is unfavorable category with a performance score of 3,800 .
\end{abstract}

Keywords: Performance Measurement, Balanced Scorecard, Cooperative

\section{PENDAHULUAN}

Kinerja merupakan hal penting yang menjadi fokus pencapaian dari suatu organisasi. Untuk dapat mengetahui seberapa jauh tujuan organisasi telah dicapai maka diperlukan pengukuran kinerja. Dengan pengukuran kinerja, akan lebih memfokuskan suatu organisasi pada apa yang akan diselesaikan dan memaksa untuk lebih berkonsentrasi pada waktu, sumber daya, dan energi dalam mencapai tujuan. Selain itu pengukuran kinerja akan memperbaiki komunikasi internal karyawan dan eksternal antara organisasi dengan customer maupun stakeholder, serta dapat membantu suatu organisasi untuk mempertanggung jawabkan program serta biayanya.

Semua bentuk organisasi perlu untuk melakukan pengukuran kinerja, demikian pula dengan organisasi koperasi. Koperasi adalah badan usaha yang beranggotakan orang-seorang atau badan hukum koperasi dengan melandaskan kegiatannya berdasarkan prinsip koperasi sekaligus sebagai gerakan ekonomi rakyat yang berdasarkan atas asas kekeluargaan [1]. Berdasarkan Keputusan Menteri Koperasi, Pengusaha Kecil dan Menengah Republik Indonesia Nomor 194/KEP/MIX/1998, tentang petunjuk pelaksanaan penilaian kesehatan koperasi simpan pinjam dan unit simpan pinjam (USP). Penilaian tingkat kesehatan KPS dan USP koperasi adalah penilaian terhadap faktor-faktor mempengaruhi kesehatan dan hasil usaha KSP dan USP dalam kurun waktu tertentu. Namun aspek yang dinilai dalam kinerja koperasi tersebut terbatas pada aspek keuangan, yaitu Permodalan, Kualitas Aktiva Produktif, Manajemen, Rentabilitas, Likuiditas. Berdasarkan 
hasil perhitungan penilaian terhadap 5 komponen di atas, ditetapkan predikat tingkat kesehatan KSP/USP yang dibagi dalam 4 golongan, yaitu : sehat, cukup sehat, kurang sehat, dan tidak sehat.

Koperasi Karyawan Perguruan Widyagama Malang merupakan koperasi yang mewadahi seluruh karyawan yang berada dalam naungan Yayasan Pembina Pendidikan Indonesia Widyagama Malang. Koperasi karyawan dengan anggota lebih dari 500 orang ini tentunya memiliki stakeholder dengan beragam kebutuhan dan keinginan terhadap kinerja koperasi. Kinerja koperasi yang diharapkan untuk ditunjukkan tidak hanya mencakup aspek keuangan saja, namun juga aspek nonkeuangan. Balanced Scorecard memberikan kerangka pengukuran kinerja yang mampu menyeimbangkan aspek keuangan dan non-keuangan.

Metode Balanced Scorecard telah banyak diterapkan diberbagai perusahaan di dunia. Menurut data bahwa lebih dari $60 \%$ perusahaan Jepang kini sudah mengadopsi kerangka kerja manajemen kinerja seperti Balanced Scorecard. Terdapat 65,5\% perusahaan responden penelitian di Australia mengklaim memiliki Balanced Scorecard untuk merancang kinerja perusahaan mereka sistem manajemen [2]. Menurut Chavan (2009) bahwa organisasi yang berbeda memiliki kebutuhan yang sangat berbeda, daerah pasar, orang, produk dan jasa, dan akan berakhir dengan Balanced Scorecard berbeda secara signifikan [3]. Hal ini menunjukan bahwa Balanced Scorecard dapat diterapkan pada organisasi koperasi. Pengukuran kinerja dengan Balanced Scorecard tersebut pada hakekatnya dapat dilakukan berdasarkan kajian berbagai aspek dan jika diperlukan dapat dilakukan modifikasi sesuai dengan karakter organisasi koperasi sebagai badan usaha dan kumpulan orang yang disebut anggota.

Pengukuran kinerja dengan menggunakan sistem informasi berbahasa pemrograman Borland Delphi, akan mempermudah proses pengukuran kinerja. Informasi yang diperlukan dapat disajikan kapan saja diperlukan. Proses penyusunan laporan periodik dan laporan pertanggun jawaban pengurus koperasi akan lebih cepat dibuat, oleh karena sistem telah menyediakan berbagai informasi yang diperlukan secara sinergi, sistematis, cepat, tepat, dan akurat.

\section{METODE PENELITIAN}

Tahapan-tahapan penelitian ini adalah sebagaimana ditampilan dalam diagram alir penelitian berikut ini.

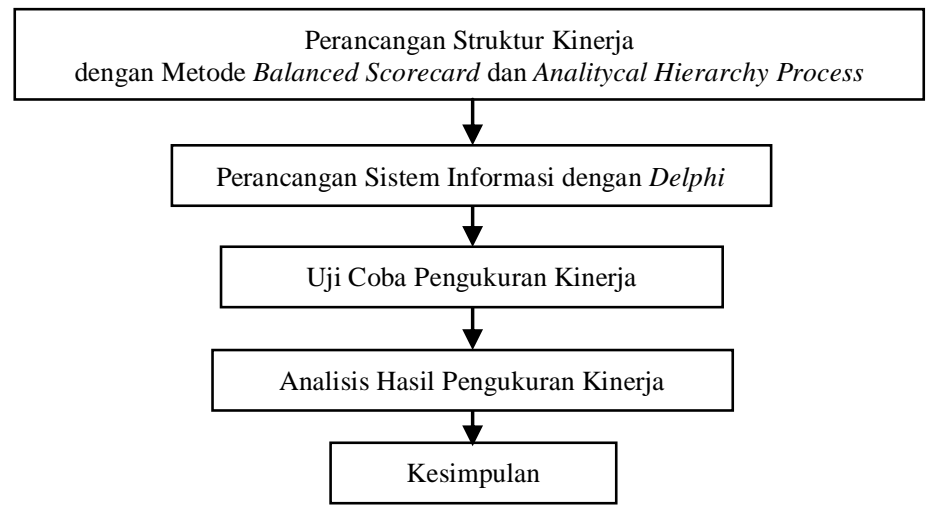

Gambar 1. Diagram Alir Penelitian

Uraian dari rancangan penelitian di atas adalah sebagai berikut:

a. Perancangan sistem pengukuran kinerja dengan Balanced Scorecard (BSC) dan Analytical Hierarchy Process (AHP).

1. Penetapan Arsitektur Pengukuran Kinerja dengan Balanced Scorecard (BSC)

i. Arsitektur pengukuran didasarkan pada unit bisnis organisasi (koperasi) yang sesuai, yaitu yang mempunyai kontrol langsung pada bidang keuangan, pelanggan, proses 
bisnis internal, dan pertumbuhan dan pembelajaran sebagaimana yang disyaratkan Balanced Scorecard.

ii. Identifikasi tujuan-tujuan strategis (Strategic Objective), yaitu menerjemahkan strategi yang telah dipilih ke dalam tujuan-tujuan strategis yang komprehensif, koheren, seimbang dan terukur.

iii. Identifikasi Key Performance Indicators (KPI). Penetapan KPI haruslah sesuai dengan tujuan-tujuan strategis yang telah terbangun dan menjadi paramater untuk mengukur keberhasilan tujuan-tujuan strategis baik berupa outcome measure maupun driver measure.

2. Pembobotan kepentingan dari masing-masing perspektif dan KPI dengan pendekatan Analytical Hierarchy Process (AHP).

Cara yang digunakan adalah dengan memberikan kuesioner kepada top manajemen atau orang yang dipandang benar-benar memahami organisasi koperasi karyawan.

3. Penetapan Target

Penetapan target sebagai milestone dilakukan berdasarkan kebijakan perusahaan sendiri dan kajian literatur. Penetapan target berdasarkan pada kebijakan koperasi. Selain itu penetapan target berdasarkan kajian literatur akan dilakukan bila didasarkan atas pengalamanpengalaman perusahaan, pendapat para pakar, dan hasil penelitian yang tertuang dalam literatur.

b. Perancangan sistem informasi dengan Borland Delphi

Berdasarkan model yang sudah dibuat selanjutnya dilakukan proses perancangan sistem informasi dengan Borland Delphi. Formula terhadap pengukuran kinerja dari masing-masing Key Performance Indicator (KPI) dikembangkan dalam sistem informasi tersebut.

c. Uji coba sistem informasi dan pengukuran kinerja

Pengujian sistem informasi pengukuran kinerja dilakukan dengan terlebih dahulu mengisikan data-data yang diperlukan bersumber dari data koperasi secara manual. Kemudian dilakukan pengukuran kinerja pada satu periode tertentu. Pengujian sistem pengukuran kinerja ini digunakan untuk mengetahui sejauh mana sistem dapat diterapkan. Pengujian ini dimaksudkan pula untuk mengevaluasi kekurangan program pengukuran kinerja berbasis Borland Delphi yang sudah dibuat, sehingga lebih mudah dalam proses perbaikannya.

d. Analisis Hasil Pengukuran

Setelah dilakukan pengukuran, kemudian langkah selanjutnya adalah menganalisis hasil dari pengukuran mana yang perlu perbaikan/ peningkatan dan mana yang harus dipertahankan. Untuk mempermudah dalam penentuan level pencapaian kinerja, dipergunakan metode Traffic Light System.

\section{Penentuan Arsitek Pengukuran}

Visi merupakan suatu hal yang sangat penting dan harus ditetapkan secara tegas sebelum suatu badan usaha atau perusahaan mulai melaksanakan aktivitas. Dengan adanya visi, suatu badan usaha atau perusahaan dapat mengetahui aktivitas apa yang harus dilakukan untuk mencapai visi yang telah ditetapkan tersebut. Adapun visi dan misi Kopkar PWGM:

Visi:

Meningkatkan peran serta dan optimalisasi sumber daya di dalam koperasi untuk membentuk usaha yang produktif dan handal sehingga dapat mewujudkan kesejahteraan dan kemandirian usaha bagi anggotanya.

\section{Misi:}

a. Mengoptimalkan dan memberdayakan aset-aset ekonomi para anggota untuk di sinergiskan dalam suatu pemberdayaan ekonomi koperasi sehingga membentuk sistem perekonomian yang kuat dan tangguh dalam persaingan dunia usaha. 
b. Meningkatkan kesadaran seluruh anggota akan manfaat bersama pentingnya koperasi melalui pendidikan perkoperasian.

c. Membentuk unit-unit usaha produktif yang sehat dan mandiri dalam upaya untuk meningkatkan kesejahteraan bagi semua anggotanya.

d. Meningkatkan produktivitas dan daya saing yang tinggi dengan mengembangkan sinergi dan partisipasi semua anggota dalam mengelola unit-unit usaha koperasi.

e. Membuktikan bahwa sistem perekonomian koperasi adalah sisitem ekonomi pemberdayaan masyarakat yang terkait sehingga koperasi dapat memberikan citra yang positif bagi kendala keterbatasan multi dimensi untuk meningkatkan pendapatan yang pada akhirnya dapat memperbaiki kesejahteraan anggota yang lebih baik.

f. Memantapkan koperasi sebagai sebuah perusahaan dengan jatidiri koperasi melalui penyelenggaraan ekonomi kerakyatan.

g. Berperan serta membantu pemerintah untuk menjalankanprogram-program pemberdayaan sehingga koperasi berperan aktif dalam meningkatkan kesejahteraan masyarakat.

Berikut hasil tujuan strategis untuk setiap perspektif balanced scorecard pada Kopkar PWGM dapat dilihat pada tabel 1. di bawah ini:

Tabel 1. Tujuan Strategis (Objective) Kopkar PWGM

\begin{tabular}{|c|c|}
\hline Perspektif & Tujuan Strategis \\
\hline \multirow{4}{*}{ Keuangan } & Meningkatkan Sisa Hasil Usaha \\
\hline & Meningkatkan ROI (Return of Invesment) \\
\hline & Meningkatkan Efisiensi pengeluaran \\
\hline & Akuntabilitas Keuangan \\
\hline \multirow{6}{*}{ Pelanggan } & Mempertahankan Hubungan Pelanggan \\
\hline & Menurunkan Jumlah Keluhan Pelanggan \\
\hline & Meningkatkan Pangsa Pasar \\
\hline & Meningkatkan Kepuasan Pelanggan \\
\hline & Pemberian Program Beasiswa thd keluarga Anggota \\
\hline & Pemberian Dana santuan untuk keluarga Anggota \\
\hline \multirow{8}{*}{$\begin{array}{l}\text { Proses Bisnis } \\
\text { Internal }\end{array}$} & Meningkatkan Pelayanan pada Anggota \\
\hline & Mengefektifkan Proses Operasional \\
\hline & Memaksimalkan Manajemen Persediaan \\
\hline & Meminimalkan Waktu Proses Peminjaman \\
\hline & Meminimalkan Tingkat Tunggakan Peminjam \\
\hline & Penerimaan Laporan Pertanggungjawaban RAT \\
\hline & Frekuensi Pelaksanaan Audit oleh Pengawas \\
\hline & Akuntabilitas Persediaan Produk/barang \\
\hline \multirow{4}{*}{$\begin{array}{l}\text { Pembelajaran } \\
\text { dan } \\
\text { Pertumbuhan }\end{array}$} & Meningkatkan Kemampuan Karyawan \\
\hline & Meningkatkan Kedisiplinan Karyawan \\
\hline & Mempertahankan Tingkat Perputaran Karyawan \\
\hline & Meningkatkan Kepuasan Karyawan \\
\hline
\end{tabular}

\section{Penentuan KPI (Key Performance Indicator)}

Penentuan ukuran kinerja pencapaian sasaran strategi diawali dengan mengetahui terlebih dahulu visi dan misi serta sasaran strategi untuk mencapai visi dan misi tersebut.Berikut adalah ukuran hasil dan ukuran pendorong kinerja untuk setiap sasaran strategis dalam perspektif balanced scorecard Kopkar PWGM.

Tabel 2. KPI Kopkar PWGM

\begin{tabular}{cll}
\hline Perspektif & \multicolumn{1}{c}{ Tujuan Strategis } & KPI \\
\hline \multirow{3}{*}{ Keuangan } & Meningkatkan Sisa Hasil Usaha & Prosentase peningkatan modal \\
& & $\begin{array}{l}\text { Prosentase peningkatan penjualan } \\
\text { Prosentase peningkatan laba } \\
\end{array}$ \\
& & Prosentase peningkatan SHU \\
\hline
\end{tabular}




\begin{tabular}{|c|c|c|}
\hline & $\begin{array}{l}\text { Meningkatkan ROI (Return of } \\
\text { Invesment) }\end{array}$ & Prosentase peningkatan nilai ROI \\
\hline & $\begin{array}{l}\text { Meningkatkan efisiensi } \\
\text { pengeluaran }\end{array}$ & $\begin{array}{l}\text { Prosentase efisiensi pengeluaran biaya operasional } \\
\text { koperasi }\end{array}$ \\
\hline & Akuntabilitas keuangan & Prosentase selisih kas secarafisik dengan catatan \\
\hline \multirow{6}{*}{ Pelanggan } & $\begin{array}{l}\text { Mempertahankan hubungan } \\
\text { pelanggan }\end{array}$ & Prosentase pelanggan lama yg loyal \\
\hline & $\begin{array}{l}\text { Menurunkan jumlah keluhan } \\
\text { pelanggan }\end{array}$ & Prosentase jumlah keluhan pelanggan yang ditangani \\
\hline & $\begin{array}{l}\text { Meningkatkan kepuasan } \\
\text { pelanggan }\end{array}$ & Prosentase tingkat kepuasan pelanggan \\
\hline & Meningkatkan pangsa pasar & Prosentase pelanggan baru \\
\hline & $\begin{array}{l}\text { Pemberian beasiswa untuk } \\
\text { keluarga anggota }\end{array}$ & $\begin{array}{l}\begin{array}{l}\text { Prosentase pemberian beasiswa untuk keluarga } \\
\text { anggota }\end{array} \\
\end{array}$ \\
\hline & $\begin{array}{l}\text { Pemberian dana santunan untuk } \\
\text { keluarga anggota }\end{array}$ & $\begin{array}{l}\text { Prosentase pemberian dana santunan untuk keluarga } \\
\text { anggota }\end{array}$ \\
\hline \multirow{8}{*}{$\begin{array}{l}\text { Proses Bisnis } \\
\text { Internal }\end{array}$} & $\begin{array}{l}\text { Meningkatkan Pelayanan pada } \\
\text { Anggota }\end{array}$ & Peningkatan standar pelayanan \\
\hline & $\begin{array}{l}\text { Mengefektifkan Proses } \\
\text { Operasional }\end{array}$ & Waktu proses operasinal dengan waktu standar \\
\hline & $\begin{array}{l}\text { Memaksimalkan Manajemen } \\
\text { Persediaan }\end{array}$ & $\begin{array}{llllll}\begin{array}{l}\text { Prosentase produk yang dijual dengan produk } \\
\text { digudang }\end{array} & & & \\
\end{array}$ \\
\hline & $\begin{array}{l}\text { Meminimalkan waktu Proses } \\
\text { Peminjaman }\end{array}$ & $\begin{array}{l}\text { Kesesuaian waktu pencairan pinjaman terhadap waktu } \\
\text { standar }\end{array}$ \\
\hline & Akuntabilitas persediaan & Prosentase selisih barang secara fisik dengan catatan \\
\hline & $\begin{array}{l}\text { Meminimalkan tingkat } \\
\text { tunggakan peminjam }\end{array}$ & $\begin{array}{l}\text { Prosentase besar nominal yang menjadi tunggakan } \\
\text { SPK } \\
\text { Prosentase besar nominal yang menjadi tunggakan } \\
\text { SPB }\end{array}$ \\
\hline & $\begin{array}{l}\text { Penerimaan laporan } \\
\text { pertanggungjawaban RAT }\end{array}$ & $\begin{array}{l}\text { Prosentase penerimaan laporan pertanggung jawaban } \\
\text { RAT }\end{array}$ \\
\hline & $\begin{array}{l}\text { Frekuensi pelaksanaan audit } \\
\text { oleh pengawas }\end{array}$ & Prosentase frekuensi pelaksanaan audit oleh pengawas \\
\hline \multirow{4}{*}{$\begin{array}{l}\text { Pembelajaran } \\
\text { dan } \\
\text { Pertumbuhan }\end{array}$} & $\begin{array}{l}\text { Meningkatkan kemampuan } \\
\text { karyawan }\end{array}$ & Jumlah pelatihan karyawan \\
\hline & $\begin{array}{l}\text { Meningkatkan kedisiplinan } \\
\text { karyawan }\end{array}$ & Prosentase presensi karyawan \\
\hline & $\begin{array}{l}\text { Meningkatkan kepuasan kerja } \\
\text { karyawan }\end{array}$ & Prosentase kepuasan dari karyawan \\
\hline & $\begin{array}{l}\text { Mempertahankan tingkat } \\
\text { perputaran karyawan }\end{array}$ & Prosentase jumlah karyawan yang keluar \\
\hline
\end{tabular}




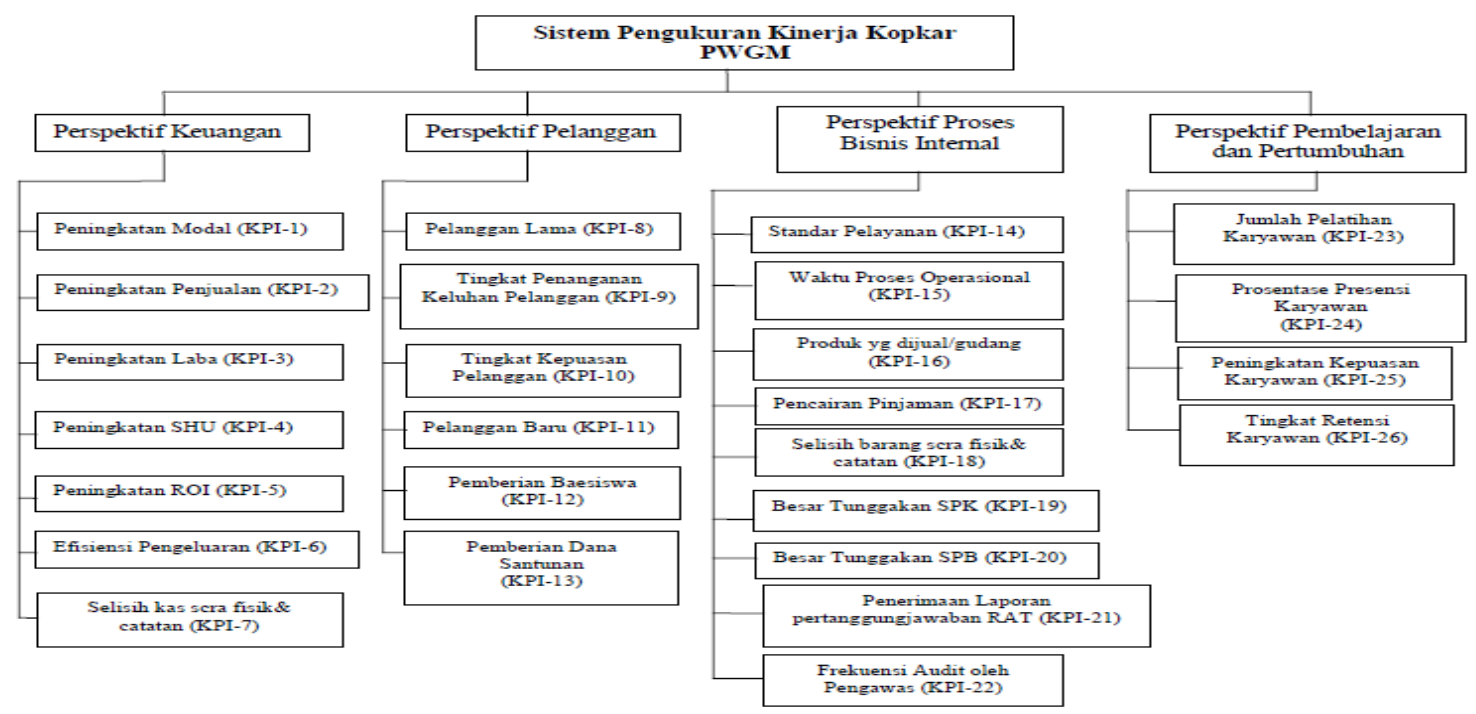

Gambar 2. Struktur Hierarki Kinerja Kopkar PWGM

\section{Hasil Pengukuran Kinerja Kopkar PWGM dengan OMAX}

Pengukuran kinerja Kopkar PWGM, berdasarkan sistem pengukuran kinerja dengan metode Balanced Scorecard (BSC) dengan menggunakan tabel Objective Matrix (OMAX) dapat dijelaskan sebagai berikut:

1. Penilaian kinerja dilakukan untuk tiap-tiap perspektif

2. Pencapaian kinerja adalah kinerja tiap-tiap atribut ukuran kinerja yang dicapai koperasi pada periode pengukuran.

Tabel 3. Penilaian Pengukuran Kinerja Kopkar PWGM pada Perspektif Keuangan

\begin{tabular}{|c|c|c|c|c|c|c|c|}
\hline KPI-1 & KPI-2 & KPI-3 & KPI-4 & KPI-5 & KPI-6 & KPI-7 & $\begin{array}{c}\text { Atribut Ukuran } \\
\text { Kinerja }\end{array}$ \\
\hline$(\%)$ & $(\%)$ & $(\%)$ & $(\%)$ & $(\%)$ & $(\%)$ & $(\%)$ & Performa \\
\hline 3.01 & 2.43 & -3594 & -31.08 & -45.99 & 5.09 & 67.57 & Pencapaian \\
\hline 12 & 2.67 & 2.45 & 3.45 & 3.24 & 6.02 & 74.32 & 10 \\
\hline 11.11 & 1.80 & -1.6 & -0.23 & -2.64 & 5.91 & 65.24 & 9 \\
\hline 10.26 & 0.87 & -5.71 & -3.97 & -8.54 & 5.85 & 56.19 & 8 \\
\hline 9.41 & -0.06 & -9.82 & -7.71 & -14.44 & 5.79 & 47.14 & 7 \\
\hline 8.56 & -0.99 & -13.93 & -11.45 & -20.34 & 5.73 & 38.09 & 6 \\
\hline 7.71 & -1.92 & -18.04 & -15.19 & -26.24 & 5.67 & 29.04 & Skor \\
\hline 6.86 & -2.85 & -22.15 & -18.93 & -32.14 & 5.61 & 19.99 & 4 \\
\hline 6.01 & -3.78 & -26.26 & -22.67 & -38.04 & 5.55 & 10.94 & 3 \\
\hline 5.01 & -5.84 & -29.49 & -25.46 & -40.69 & 5.35 & -7.93 & 2 \\
\hline 4.01 & -7.92 & -32.72 & -29.27 & -43.34 & 5.22 & -26.78 & 1 \\
\hline 3.01 & -10 & -35.94 & -31.08 & -45.99 & 5.09 & -45.65 & 0 \\
\hline 0 & 9 & 0 & 0 & 0 & 0 & 9 & Skor \\
\hline 0.150 & 0.136 & 0.147 & 0.201 & 0.087 & 0.128 & 0.151 & Bobot \\
\hline 0 & 1.224 & 0 & 0 & 0 & 0 & 1.359 & Nilai \\
\hline \multicolumn{7}{|c|}{ Pencapaian Kinerja Keuangan 2012} & 2.583 \\
\hline \multicolumn{7}{|c|}{ Bobot Kinerja Keuangan } & 0.540 \\
\hline \multicolumn{7}{|c|}{ Index Pencapaian Kinerja Keuangan } & $\mathbf{1 . 3 9 4 8 2}$ \\
\hline
\end{tabular}

Tabel 4. Penilaian Pengukuran Kinerja Kopkar PWGM pada Perspektif Pelanggan

\begin{tabular}{|c|c|c|c|c|c|c|}
\hline KPI-8 & KPI-9 & KPI-10 & KPI-11 & KPI-12 & KPI-13 & $\begin{array}{c}\text { Atribut Ukuran } \\
\text { Kinerja }\end{array}$ \\
\hline$(\%)$ & $(\%)$ & $(\%)$ & $(\%)$ & $(\%)$ & $(\%)$ & Performa \\
\hline 22.51 & 66.67 & 2.31 & 1.85 & 100 & 90 & Pencapaian \\
\hline 24.76 & 72.6 & 2.96 & 5.14 & 100 & 100 & Skor \\
\hline
\end{tabular}




\begin{tabular}{cccccccc}
24.29 & 71.02 & 2.77 & 4.95 & 92.6 & 94.26 & 9 & \\
23.86 & 69.5 & 2.63 & 4.77 & 85.5 & 88.55 & 8 & \\
23.43 & 67.98 & 2.49 & 4.59 & 78.4 & 82.84 & 7 & \\
23 & 66.46 & 2.35 & 4.41 & 71.3 & 77.13 & 6 & \\
22.57 & 64.94 & 2.21 & 4.23 & 64.2 & 71.42 & 5 & \\
22.14 & 63.42 & 2.07 & 4.05 & 57.1 & 65.71 & 4 & \\
21.71 & 61.90 & 1.93 & 3.87 & 50 & 60 & 3 & \\
21.97 & 60.30 & 1.71 & 3.19 & 36.6 & 43.32 & 2 & \\
21.17 & 58.72 & 1.49 & 2.52 & 23.3 & 26.66 & 1 & \\
20.91 & 57.14 & 1.27 & 1.85 & 10 & 10 & 0 & Skor \\
\hline 4 & 6 & 5 & 0 & 10 & 8 & & Bobot \\
\hline 0.150 & 0.230 & 0.241 & 0.155 & 0.122 & 0.102 & $\mathbf{5 . 2 2 1}$ \\
\hline 0.6 & 1.38 & 1.205 & 0 & 1.22 & 0.816 & & 1.221714 \\
\hline \multicolumn{7}{l}{ Pencapaian Kinerja Pelanggan } \\
\hline \multicolumn{7}{l}{ Bobot Kinerja Pelanggan Pencapaian Kinerja Pelanggan }
\end{tabular}

Tabel 5. Penilaian Pengukuran Kinerja Kopkar PWGM pada Perspektif Proses Bisnis Internal

\begin{tabular}{|c|c|c|c|c|c|c|c|c|c|}
\hline KPI-14 & KPI-15 & KPI-16 & KPI-17 & KPI-18 & KPI-19 & KPI-20 & KPI-21 & KPI-22 & $\begin{array}{c}\text { Atribut Ukuran } \\
\text { Kinerja }\end{array}$ \\
\hline$(\%)$ & $(\%)$ & $(\%)$ & $(\%)$ & $(\%)$ & $(\%)$ & $(\%)$ & $(\%)$ & $(\%)$ & Performa \\
\hline 60 & 55 & 48 & 65 & -2.44 & 38 & 42 & 95 & 133.3 & Pencapaian \\
\hline 85 & 80 & 80 & 85 & 2 & 20 & 15 & 100 & 100 & 10 \\
\hline 80.68 & 75.68 & 75.5 & 80 & 0.02 & 22.35 & 17.14 & 96.1 & 98.22 & 9 \\
\hline 76.4 & 71.4 & 70 & 75 & -2.01 & 24.7 & 19.28 & 92.2 & 96.44 & 8 \\
\hline 72.12 & 67.12 & 64.5 & 70 & -4.04 & 27.05 & 21.42 & 88.3 & 94.66 & 7 \\
\hline 67.84 & 62.84 & 59 & 65 & -6.07 & 29.4 & 23.56 & 84.4 & 92.88 & 6 \\
\hline 63.56 & 58.56 & 53.5 & 60 & -8.1 & 31.75 & 25.7 & 80.5 & 91.1 & Skor \\
\hline 59.28 & 54.28 & 48 & 55 & -10.13 & 34.1 & 27.84 & 76.6 & 89.32 & 4 \\
\hline 55 & 50 & 43.50 & 5050 & -12.16 & 36.5 & 30 & 72.7 & 87.54 & 3 \\
\hline 40 & 41.6 & 42 & 43.32 & 15.41 & 45 & 48 & 71.03 & 86.16 & 2 \\
\hline 25 & 33.3 & 40.5 & 36.67 & -18.64 & 53.5 & 66 & 69.36 & 84.78 & 1 \\
\hline 10 & 25 & 39 & 30 & -21.89 & 62 & 84 & 67.69 & 83.4 & 0 \\
\hline 4 & 4 & 4 & 6 & 8 & 3 & 3 & 8 & 10 & Skor \\
\hline 0.186 & 0.104 & 0.084 & 0.082 & 0.100 & 0.110 & 0.163 & 0.083 & 0.088 & Bobot \\
\hline 0.744 & 0.416 & 0.336 & 0.492 & 0.8 & 0.33 & 0.489 & 0.664 & 0.88 & Nilai \\
\hline \multicolumn{9}{|c|}{ Pencapaian Kinerja Proses Bisnis Internasional } & 2.583 \\
\hline \multicolumn{9}{|c|}{ Bobot Kinerja Proses Bisnis Internasional } & 0.540 \\
\hline \multicolumn{9}{|c|}{ Index Pencapaian Kinerja Proses Bisnis Internasional } & $\mathbf{1 . 3 9 4 8 2}$ \\
\hline
\end{tabular}

Tabel 6. Penilaian pengukuran kinerja Kopkar PWGM pada perspektif pembelajaran dan pertumbuhan

\begin{tabular}{cccccc}
\hline KPI-23 & KPI-24 & KPI-25 & KPI-26 & $\begin{array}{c}\text { Atribut Ukuran } \\
\text { Kinerja }\end{array}$ \\
\hline$(\%)$ & $(\%)$ & $(\%)$ & $(\%)$ & & $\begin{array}{c}\text { Performa } \\
\text { Pencapaian }\end{array}$ \\
\hline 66.6 & 84.67 & 2.36 & 8.33 & & \\
\hline 83.25 & 95 & 3.24 & 8.33 & 10 & \\
78.5 & 93.02 & 3.09 & 7.32 & 9 & \\
73.75 & 91.1 & 2.94 & 6.35 & 8 & \\
69 & 89.18 & 2.79 & 5.38 & 7 & \\
64.25 & 87.26 & 2.64 & 4.41 & 6 & \\
59.5 & 85.34 & 2.49 & 3.44 & 5 & Skor \\
54.75 & 83.42 & 2.34 & 2.47 & 4 & \\
50 & 81.50 & 2.19 & 1.5 & 3 & \\
44.45 & 80.39 & 1.98 & 1 & 2 & \\
38.9 & 79.36 & 1.78 & 0.5 & 1 & \\
33.35 & 78.33 & 1.58 & 0 & 0 & \\
\hline 6 & 4 & 4 & 10 & & Skor
\end{tabular}




\begin{tabular}{|c|c|c|c|c|}
\hline 0.523 & 0.164 & 0.232 & 0.081 & Bobot \\
\hline 3.138 & 0.656 & 0.928 & 0.81 & Nilai \\
\hline \multicolumn{4}{|c|}{$\begin{array}{l}\text { Pencapaian Kinerja Pembelajaran dan } \\
\text { Pertumbuhan }\end{array}$} & 5.532 \\
\hline \multicolumn{4}{|c|}{ Bobot Kinerja Pembelajaran dan Pertumbuhan } & 0.057 \\
\hline \multicolumn{4}{|c|}{$\begin{array}{l}\text { Index Pencapaian Kinerja Pembelajaran dan } \\
\text { Pertumbuhan }\end{array}$} & 0.315324 \\
\hline
\end{tabular}

\section{Analisis Hasil Pengukuran dan Penilaian Kinerja Kopkar PWGM dengan Model Balanced Scorecard (BSC) dan Objective Matrix (OMAX)}

Berdasarkan hasil pengukuran dan penilaian kinerja Kopkar PWGM tahun 2010 yang dilakukan dengan menggunakan metode Objective matrix, diperoleh pencapaian kinerja untuk masing-masing perspektif. Adapun hasilnya adalah sebagai berikut:

1. Pencapaian perspektif keuangan $=2,583$

2. Pencapaian perspektif pelanggan $=5,221$

3. Pencapaian perspektif proses bisnis internal $=5,151$

4. Pencapaianperspektifperkembangan\&pertumbuhan $\quad=5,532$

Dari hasil tersebut, dapat dilihat perspektif pembelajaran dan pertumbuhan memiliki pencapaian tertinggi, diikuti oleh perspektif pelanggan, perspektif proses bisnis internal, kemudian perspektif keuangan.

Indeks pencapaian kinerja secara keseluruhan $=3,800$. Dari hasil tersebut dapat dilihat bahwa Kopkar PWGM berada dalam kategori Kurang baik.

Untuk KPI yang termasuk kategori kurang baik (skor 1-4) dan sedang (skor 5-7) atau pencapaiannya benar-benar di bawah target (skor 0), maka perhatian manajemen harus lebih fokus pada KPI tersebut, untuk dapat mendongkrak atau meningkatkan kinerjanya dengan tetap mempertahankan ataupun lebih meningkatkan kinerja KPI yang telah mencapai maupun mendekati target tersebut.

\section{Analisis pencapaian kinerja masing-masing KPI \\ Perspektif Keuangan}

Pencapaian kinerja untuk perspektif keuangan sebesar 2,583, hal ini menunjukkan bahwa kinerja perspektif tersebut masuk dalam kategori kurang baik.:

a. Kinerja KPI kategori baik adalah peningkatan penjualan (KPI-2) dengan skor 9 dan kesesuaian selisih kas antara fisik dengan catatan (KPI-7) dengan skor 9. Dari kedua KPI tersebut inisiatif yang dapat dilakukan adalah dengan mempertahankan kinerja indikator tersebut.

b. Kinerja KPI kategori sangat kurang baik adalah peningkatan modal (KPI-1) dengan skor 0, peningkatan laba (KPI-3) dengan skor 0, peningkatan SHU (KPI-4) dengan skor 0, peningkatan ROI (KPI-5) dengan skor 0, dan efisiensi pengeluaran (KPI-6) dengan skor 0 . Dari kelima KPI tersebut inisiatif yang dapat dilakukan adalah dengan meningkatkan kinerja indikator tersebut. Pada KPI-3 dan KPI-4 laba serta SHU yang didapat selalu turun dari tahun ketahun, hal ini terjadi karena biaya- biaya yang dikeluarkan cukup besar dibanding pendapatan dan penjualan. Selain itu merosotnya tingkat kepuasan pelanggan, yang diakibatkan oleh pelayanan karyawan yang dianggap kurang baik, diversifikasi produk yang kurang, harga yang kurang kompetitif, sehinggan menurunkan minat pelanggan untuk berbelanja. Selain itu juga diakibatkan oleh frekuensi/jumlah pelatihan karyawan yang kurang ideal, atasan yang kurang bijak terhadap bawahan serta karyawan sendiri yang tidak puas terhadap pekerjannya. Hal ini akan mengakibatkan kurang adanya teamwork antar karyawan,serta tidak adanya self owner dalam diri karyawan untuk lebih memajukan Kopkar. Karena SHU selalu turun, maka modal pun juga akan turut turun. Untuk KPI-5, nilai ROI kecil, hal ini diakibatkan karena laba yang diperoleh juga kecil. Untuk meningkatkan nilai 
ROI, hal yang dilakukan adalah meningkatkan laba dan SHU, meminimalkan biaya-biaya yang dikeluarkan koperasi, serta meningkatkan pangsa pasar.

\section{Perspektif Pelanggan}

Pencapaian kinerja untuk perspektif pelanggan sebesar 5,221, hal ini menunjukkan bahwa kinerja perspektif tersebut masuk dalam kategori sedang.

a. Kinerja KPI kategori sangat baik adalah pemberian beasiswa kepada keluarga anggota (KPI12) dengan skor 10. Untuk KPI tersebut inisiatif yang dapat dilakukan adalah dengan mempertahankan kinerja indikator tersebut.

b. Kinerja KPI kategori baik adalah pemberian dana santunan (KPI-13) dengan skor 8. KPI tersebut inisiatif yang dapat dilakukan adalah dengan mempertahankan kinerja indikator tersebut.

c. Kinerja KPI kategori sedang adalah tingkat penanganan keluhan pelanggan (KPI-9) dengan skor 6, tingkat kepuasan pelanggan (KPI-10) dengan skor 5. Dari kedua KPI tersebut inisiatif yang dapat dilakukan adalah dengan meningkatkan kinerja indikator tersebut.

d. Kinerja KPI kategori kurang baik dan sangan kurang baik pelanggan lama yang loyal/aktif (KPI-8) dengan skor 3, dan jumlah pelanggan baru (KPI-11) dengan skor 0. Untuk mempertahankan pelanggan dan meningkatkan jumlah pelanggan baru, hal yang bisa dilakukan adalah dengan lebih meningkatkan pelayanan, mengatasi keluhan dari pelanggan serta dapat menjaga silaturahmi dengan pelanggan dan mempertahankan faktor-faktor yang sudah terjalin dengan baik, sehingga Kopkar PWGM dapat mencapai target yang diinginkan.

\section{Perspektif Proses Bisnis Internal}

Pencapaian kinerja untuk perspektif proses bisnis internal sebesar 5,151, hal ini menunjukkan bahwa kinerja perspektif tersebut masuk dalam kategori sedang.

a. Kinerja KPI kategori sangat baik adalah frekuensi pelaksanaan audit oleh pengawas (KPI-22) dengan skor 10. Untuk KPI tersebut inisiatif yang dapat dilakukan adalah dengan mempertahankan kinerja indikator tersebut.

b. Kinerja KPI kategori baik adalah kesesuaian selisih barang secara fisik dengan catatan (KPI18) dengan skor 8, dan penerimaan laporan pertanggungjawaban RAT (KPI-21) dengan skor 8. Untuk KPI tersebut inisiatif yang dapat dilakukan adalah dengan mempertahankan kinerja indikator tersebut.

c. Kinerja KPI kategori sedang adalah kesesuaian lama waktu pencairan peminjaman dengan waktu standar (KPI-17) dengan skor 6,. Dari KPI tersebut inisiatif yang dapat dilakukan adalah dengan meningkatkan kinerja indikator tersebut.

d. Kinerja KPI kategori kurang baik adalah peningkatan standar pelayanan (KPI-14) dengan skor 4, kesesuaian waktu proses operasional dengan waktu standar (KPI-15) dengan skor 4, prosentase produk yang dijual dengan produk di gudang (KPI-16) dengan skor 4, besar tunggakan di SPK (KPI-19) dengan skor 3, dan besar tunggakan di SPB (KPI-20) dengan skor 3. Untuk kelima KPI tersebut inisiatif yang dapat dilakukan adalah dengan meningkatkan kinerja indikator tersebut. Pada KPI-14, untuk meningkatkan standar pelayanan hal yang bisa dilakukan adalah dengan membuat SOP ( Standard Operational Prosedur) yang baku, pelatihan karyawan, meningkatkan kepuasan karyawan itu sendiri. Hal ini harus dilakukan karena sangat berpengaruh terhadap kelangsungan hidup koperasi serta dapat memperlihatkan citra/image dari Kopkar PWGM itu sendiri. Untuk KPI-15, untuk mengefektifkan proses opersional, pihak Kopkar harus sering memberikan pengarahan dan pelatihan agar karyawan yang berada dibagian kasir lebih tanggap dan tangkas dalam melayani pelanggan. Untuk KPI-16, Pihak Kopkar harus selalu mengecek selalu persediaan produk di gudang dan rak penjualan, agar tidak terjadi kekosongan barang pada rak penjualan. Pada KPI-19 dan KPI20, untuk menurunkan besar tunggakan di SPK dan SPB hal yang bisa dilakukan adalah 
menyeleksi peminjam berdasarkan kelayakan dan persyaratan yang ditetapkan, track record si peminjam, dan mempertegas sangsi kepada si penunggak.

\section{Perspektif Pembelajaran dan Pertumbuhan}

Pencapaian kinerja untuk perspektif pembelajaran dan pertumbuhan sebesar 5,532, hal ini menunjukkan bahwa kinerja perspektif tersebut masuk dalam kategori sedang.

a. Kinerja KPI kategori sangat baik adalah prosentase retensi/ tingkat perputaran karyawan (KPI-26) dengan skor 10. Untuk KPI tersebut inisiatif yang dapat dilakukan adalah dengan mempertahankan kinerja indikator tersebut.

b. Kinerja KPI kategori sedang adalah adalah jumlah pelatihan karyawan (KPI-23) dengan skor 6. Untuk KPI tersebut inisiatif yang dapat dilakukan adalah dengan meningkatkan kinerja indikator tersebut.

c. Kinerja KPI kategori kurang baik adalah prosentase presensi karyawan (KPI-24) dengan skor 4, dan tingkat kepuasan karyawan (KPI-25) dengan skor 4. Untuk meningkatkan kepuasan karyawan hal yang bisa dilakukan adalah meningkatkan kemampuan karyawan dan meningkatkan SHU. Dengan meningkatkan kemampuan karyawan akan lebih memotivasi diri untuk lebih memajukan koperasi, serta meningkatkan faktor-faktor yang membuat karyawan puas terhadap pekerjannya, misalnya kenaikan gaji, team work dengan rekan kerja, pekerjaan yang sesuai keahlian, atasan yang bijak dan membantu karyawan apabila terjadi kesulitan, serta kenaikan jabatan. Apabila karyawan merasa puas terhadap Kopkar PWGM, maka mereka akan lebih disiplin dan mempunyai semangat kerja yang tinggi. Selain itu dengan SHU yang meningkat, dapat mensejahterakan karyawan sesuai dengan visi misi koperasi itu sendiri.

\section{KESIMPULAN}

Rancangan sistem pengukuran kinerja dengan metode Balanced Scorecard berbasis Borland Delphi dapat mempercepat proses pengukuran kinerja Kopkar PWGM.

Berdasarkan rancangan struktur hierarki sistem pengukuran kinerja Kopkar PWGM dapat diperoleh bahwa Kopkar PWGM memiliki total 26 KPI, yaitu perspektif keuangan memiliki 7 KPI, untuk perspektif pelanggan memiliki $6 \mathrm{KPI}$, untuk perspektif proses bisnis internal memiliki 9 KPI, dan untuk perspektif pembelajaran dan pertumbuhan memiliki 4 KPI. Untuk lebih detailnya dapat dilihat pada gambar dibawah ini.

Hasil pengukuran kinerja Kopkar PWGM diperoleh total indeks pencapaian sebesar 3,800. Dari hasil tersebut dapat dilihat bahwa Kopkar PWGM berada dalam kategori kurang baik. Hasil indeks pencapaian kinerja untuk masing-masing perspektif, diantaranya perspektif keuangan memiliki indeks pencapaian tertinggi dengan 1,394, diikuti perspektif pelanggan 1,221 dan perspektif proses bisnis internal 0,870 kemudian perspektif pembelajaran dan pertumbuhan sebesar 0,315.

Analisis tentang hasil uji coba konsep balanced scorecard sebagai sistem pengukuran kinerja di Kopkar PWGM yaitu untuk KPI yang masuk dalam kategori sangat kurang baik adalah peningkatan modal (KPI-1), peningkatan laba (KPI-3), peningkatan SHU (KPI-4), peningkatan ROI (KPI-5), efisiensi pengeluaran (KPI-6), dan pelanggan baru (KPI-11). Untuk KPI-KPI tersebut harap lebih fokus dalam meningkatkan kinerjanya karena sangat berpengaruh dalam perkembangan Kopkar PWGM.

\section{DAFTAR PUSTAKA}

[1]. Undang-Undang Republik Indonesia No. 25 Tahun 1992 Tentang Perkoperasian Indonesia.

[2]. Neely, A., D., Yaghi, B. \& Youell, N., 2008, Enterprise Performance Management: The UK State of the Art, Oracle and Cranfield School of Management, Disponibil LA.

[3]. Meena Chavan, 2009, The balanced scorecard: a new challenge, Journal of Management Development Volume: 28 Issue: 5. 